\title{
The political economy of 'impeachment' in Brazil: an assessment of the Temer interlude (2016-2018)
}

\author{
Vitor Eduardo Schincariol* / Paris Yeros ${ }^{1}$ \\ Federal University of ABC - Center for Engineering, Modeling and Applied Social Sciences - Brazil
}

Received: 14 October 2018 / Accepted: 27 November 2018

\begin{abstract}
This article focuses on the impeachment process of Dilma Rousseff in Brazil, as well as the economic policies and the performance of the economy under the Temer administration, between 2016 and 2018. The article shows that Dilma Rousseff's impeachment favored a stronger neoliberal thrust advocated especially by financial markets, and that contrary to the proclaimed objectives of the new administration, the economic policies adopted against recession did not lead to an expressive economic recovery, or to an improvement of the fiscal situation of the central government. Instead, the accelerated privatization and denationalization of the economy since the impeachment has further perpetuated stagnation, reinforced indebtedness, and reduced the capacity of the central government to respond.
\end{abstract}

\section{Keywords}

Brazilian economy / Economic policies / Political economy / Macroeconomic / Economic development.

\section{A economía política do impeachment no Brasil: unha avaliación da Administración Temer (2016-2018)}

\section{Resumo}

Este artigo céntrase no proceso de "impeachment" de Dilma Rousseff en Brasil, así como nas políticas económicas aplicadas e da marcha da economía baixo a administración de Temer, entre 2016 y 2018. 0 artigo amosa que o exercicio de Dilma Rousseff favoreceu un empuxe neoliberal máis forte defendido especialmente polos mercados financeiros e que, ao contrario dos obxectivos proclamados da nova Administración, as políticas económicas adoptadas contra a recesión non supuxeron unha recuperación económica nin unha mellora da situación fiscal do Goberno central. Pola contra, a privatización acelerada e a desnacionalización da economía desde o impeachment perpetuou aínda máis o estancamento, reforzou o endebedamento e reduciu a capacidade de resposta do Goberno central.

\section{Palabras clave}

Economía brasileira / Políticas económicas / Economía política / Macroeconomía / Desenvolvemento económico.

JEL Codes: E60, P16, 01.

\section{Introduction}

Dilma Rousseff's impeachment in 2016 was celebrated in the corporate and financial markets as a necessity for the recuperation of the Brazilian economy, whose Gross Domestic Product (GDP) faced a continuous sharp deceleration since 2011 (with a brief exception in 2013; see figure 1). A government team headed by then-Vice President Michel Temer replaced Dilma's administration, which was elected by direct vote in 2014. The new economic team assumed office under the label of a 'renovator'

\footnotetext{
* Corresponding author: vitor.schincariol@ufabc.edu.br

1 We would like to thank Leda Paulani and the reviewer of the Revista Galega de Economía for reading and commenting on an earlier version of this work. Eventual mistakes are the authors' responsibility.
} 
administration, calling its program of government a 'Bridge to the Future'. This article seeks to evaluate the performance of the Temer administration and its economic policies after two years of the impeachment process (2016-2018). We first contextualize the impeachment and describe and analyze the 'Bridge to the Future' program. We then analyze the evolution of Brazil's macroeconomic scenario up to the period immediately preceding the presidential elections of 2018.

Our analysis uses the main existing official macroeconomic indicators. Websites of the main local newspapers are used to refer to some of the main facts mentioned. Starting from the analysis of the pattern of the economic policies and the structural performance of the economy in these two years, we interpret the results achieved by the adopted economic policies, also analyzing the more general conditions of the Brazilian economy. It is argued that the results obtained do not favor a positive analysis of the Temer administration, from the point of view of the labor market conditions, the state budget or even the nominal rates of economic growth. The interest and justification for this study lie in the scarcity of academic analyses of the administration that took power in Brazil in May 2016. The article is divided into three sections: the first broadly addresses the political economic dynamics of the period; the second provides a summary of the policies adopted by the government; and the third proceeds with an assessment of the country's macroeconomic performance.

\section{Dilma's impeachment}

In broader terms, Dilma's impeachment interrupted the continuity of a democratically re-elected federal administration, under a heavy escalation of political conflict, street fights, and the shadow of censorship returning openly to the country, such as prohibitions on naming the impeachment a 'coup' (see Sputnik News, 05-19-2016; for interpretations of the Lula and Dilma administrations, see for example Anderson, 2016; Bastos, 2012; Bresser-Pereira, 2007, 2015; Cosenza, 2018; Pochmann, 2012; Saad \& Arestis (Eds.), 2007; Schincariol, 2012; Secco, 2011; and Singer, 2012). Although Dilma implemented since 2015 a fairly orthodox program in economic terms (with the application of a fiscal adjustment and attacks on labor laws) ${ }^{2}$, Vice President Temer, once in power, formed a government team with a much more conservative view.

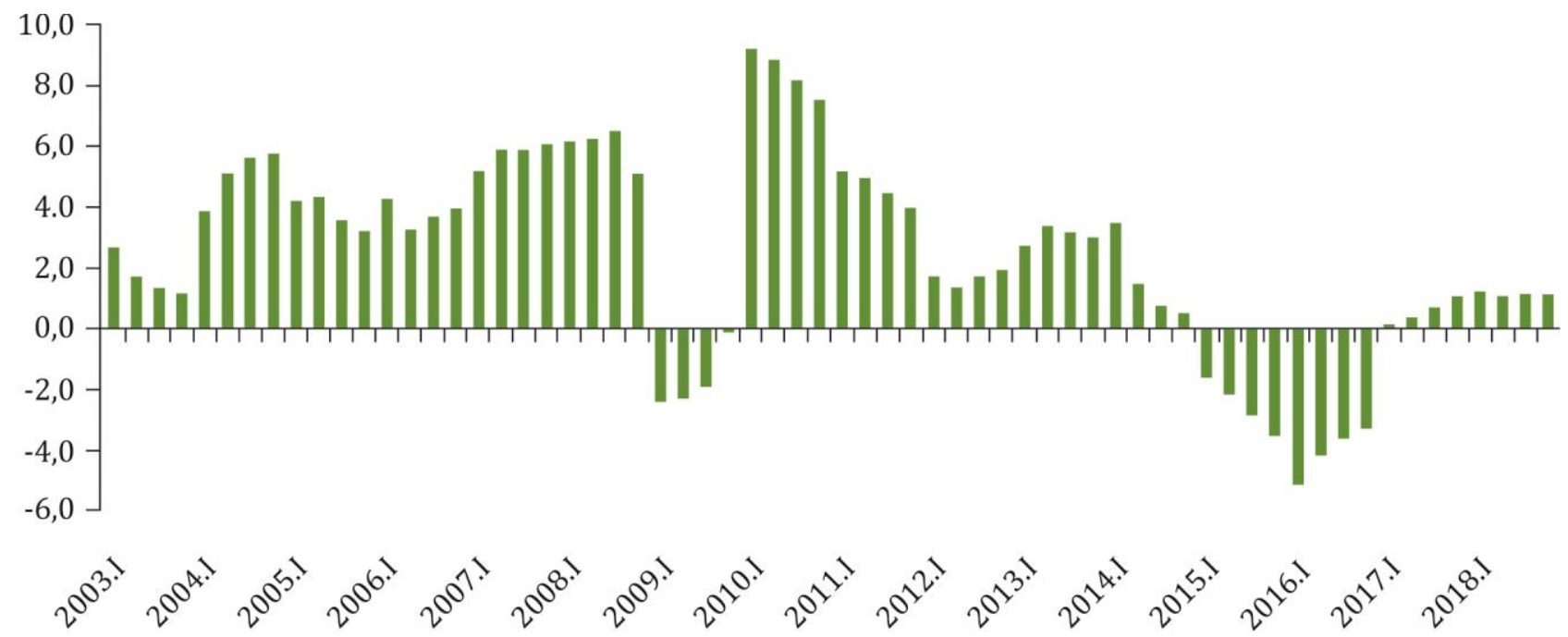

Figure 1. Brazil. Gross domestic product. Accumulated rate on a quarterly basis (\%) 2003-2018. Source: Instituto Brasileiro de Geografia e Estatística (IBGE)3.

2 The signing of the so-called 'anti-terrorism law', which significantly increased the state's repression power on the streets, including social movements (Law 13.260 of 2016), also contributed to Dilma's weakening.

${ }^{3}$ All data for tables and figures were accessed in June 2019. Exceptions are duly mentioned. 
As above mentioned, Temer and his supporters officially denied any charge of a coup. Critics, on the other hand, argued that a destabilizing break had occurred, with a new type of more refined antidemocratic procedure through a legislative deposition linked to the judicialization of economic policy (the phenomenon has already amassed extensive academic literature; see Sieder et alii [eds.], 2005). Even as Temer denied the 'coup', the new [P]MDB-led government would in fact perform a radical break with the post-1988 institutional rules of the game, notwithstanding the victorious PT coalition two years earlier. The behavior of the victorious forces in parliament, and elsewhere, the bombastic, sarcastic, or cynical statements, the virulence of many etc., showed that they had been waiting too long for such a reversal of the political framework. And this showed how, to some of the so called liberals, along with some crypto-fascists, democracy seemed to have reached the limit of the tolerable in the four successive defeats in the presidential elections.

It was evident that this component, and several others not officially stated, were reasons for the desire to overthrow Dilma, particularly the successive increases in minimum wages, which tightened corporate profit margins at the end of the previous period of prosperity (see Schincariol, 2017, statistical appendix) ${ }^{4}$. For the most exalted, the process was even 'revolutionary', as the federal deputy Jair Bolsonaro -who, in his vote in favor of the impeachment in May 2016, praised the coup of 1964 (that initiated Brazil's military dictatorship) and the torturer of Dilma in jail (she was imprisoned during that period). This deputy would go on to stand as a presidential candidate and win in 2018.

From the point of view of the international interests, there was no indication, either on the part of the US authorities or the Chinese, that the impeachment process would not be respected. It was a process that, although eventually supported from abroad, had enormous bases of local operators, in both the public and private spheres. Did the members of the Senate and Chamber of Deputies receive briberies to vote in favor of impeachment? It is not possible to know, but Temer knew that he had the implicit support of the international conglomerates, including those interested in the Pre-salt Petroleum layer on the south-east coast of the country. Until then, Petrobras was being more or less favored by the policies of Dilma, although with the contradictions pointed out by experts such as Ildo Sauer (see, for example, his interview in the program Brasilianas, 10-10-2013). The new Temer government signaled more trade liberalization, to the detriment of Mercosur, putting aside any protectionist or real nationalist plan. The right-wing Argentinean president, Mauricio Macri, who also militated against Mercosur, also hastened to defend the smoothness of the impeachment process and to lead a free trade agreement between Mercosur and the European Union (El País, 02/02/2017).

Who would be some of the key members of the new government? Let's mention some examples. It should be noted in advance that the Government extinguished, under provisional law 726, the Ministry of Women, Racial Equality, Youth and Human Rights, while the Special Secretariat for Policies for the Promotion of Racial Equality (SEPPIR) and the National Council for the Promotion of Racial Equality (CNPIR) were absorbed in the new Ministry of Justice and Citizenship. The extinction showed the tone of the new administration in the face of racial and gender inequalities: they were to be subordinated to the Ministry of Justice, that is, losing the importance that previously had justified an exclusive ministry. They were now subordinated to the judiciary, one of the fundamental sectors of the anti-Dilma articulation. The Ministry of Agrarian Development (MDA) was also extinguished and demoted to a Secretariat of the Presidential Civil House (Decree 8780), showing that the government would block through the direct use of the executive power any serious discussion on agrarian reform.

The new finance minister was Henrique Meirelles, former president of the Central Bank between 2003 and 2011, during the Lula administration. He also worked for the Bank of Boston and, like Temer, had fallen out with PT. Meirelles is also an American citizen (Rede Brasil Atual, 09-02-2016). The new president of the Central Bank was Ilan Goldfajn, born in Haifa, Israel. He had also come from a

\footnotetext{
${ }^{4}$ Some members of the Senate who voted for impeachment confessed, without this being widely publicized, that there was in fact no crime of responsibility on behalf of Dilma, but that the impeachment was still 'necessary' (O Globo, 08/31/2016).
} 
long career in the financial sector. For the Ministry of Education, Temer had originally named Mendonça Filho ${ }^{5}$. The extent of his perspectives on education could be inferred when Mendonça met a former porn actor in the Ministry of Education so as to 'receive proposals about education' (Uol Educação, May 25, 2016). Mendonça also implicitly endorsed the conservative project of a 'partyless school'. The politician Geddel Vieira, former Minister of National Integration (PMDB) during the Lula administration (2007-2010), assumed the position of Chief Minister of the House of Government. He was later arrested for money laundering and criminal association, after an unaccounted sum of R\$ 51 million was found in an apartment in Salvador, which was assigned to him (Veja, 12/04/2017).

The government even announced the extinction of the Ministry of Culture, but declined after negative repercussions. Prime Minister Marcelo Calero resigned days after his inauguration, denouncing irregularities among the ministers, particularly referring to the aforementioned Geddel Vieira. In foreign relations, José Serra -once a progressive economist now converted to neoconservatism- took over. Serra demonstrated that he did not know, for example, in a live interview, which countries composed the BRICS group (Brazil, Russia, India, China and South Africa) (Revista Forum, 12/17/2016). Aloysio Nunes, also a senator from the PSDB with a leftist past, succeeded him because of Serra's health problems. Nunes hastened to visit the United States a day after the impeachment (Rede Brasil Atual, 19/04/2016). He would cooperate more or less openly with the US State Department's anti-Maduro policy (Agência Brasil, 02/06/2017), often declaring that Venezuela was experiencing a 'dictatorship'.

The Minister of Planning, Romero Jucá (PMDB), remained only eleven days in power, after audio revelations in which he articulated the fall of Dilma with Sérgio Machado (ex-senator by the PSDB), given the 'necessity to stop the [Lava a Jato operation]', in which Dilma did not intervene (Folha de São Paulo, 05/23/2016). In turn, over the months, Temer himself would be accused, including with audio recordings, of passive corruption and illicit favoritism, accusations widely reported by the media and suggested as possible causes of an eventual resignation. Temer lost several other ministers over the course of two years (O Estado de São Paulo, 02/21/2018).

Beyond the spheres of government and the new allegations of corruption -which, it should be remembered, also existed in the previous administrations- the most important issues in 2016, in terms of the Brazilian political economy, now were: the enormous change of the political climate towards a radicalization of the right wing forces, and the abrupt change of the modus vivendi of the institutions; the changes made by the government policies, and their transcendent consequences. We will now summarize the main decisions and measures adopted by the government in the 2016-2018 period.

\section{The new agenda and the 'Bridge to the future'}

Temer's government adopted an agenda entitled 'A bridge to the future', assigned to the Ulysses Guimarães institute, maintained by the [P]MDB. This was in October 2015, when Dilma was still in power. The 'split' between Dilma and PMDB had already occurred, including with the then-vice president himself. This program was a neoliberal reaction to the more or less 'developmentalist' years of Dilma and Lula's government, which had broad support in Brazil, including intellectuals (see for example Bacha e De Bolle (Eds.), 2013; Bonelli e Pessoa (Eds.), 2010; Duarte, Silber \& Guilhoto, 2011; Giambiagi \& Além, 2008). The document, which signaled the maintenance of the inflation targeting system, claimed all the items of the neoliberal line of economic thought, but with daring new features.

In international relations, the document saw no enemies; it implicitly assumed the United States as a natural and superior ally. In domestic relations, it called for the 'pacification' of 'Brazilian society'. There would be no divergent social classes and interests. It was gloomily stated that 'all the initiatives

\footnotetext{
5 Member of the 'Democratic Party', formerly the 'Party of the Liberal Front' (PFL), dissident of the former 'Social Democratic Party' (PDS), which in turn came from the old 'Arena', the official party of the dictatorial regime (1964-1985).
} 
presented here are a necessity, and almost a consensus, in the country' (Fundação Ulysses Guimarães/PMDB, 2015, p. 2)6. Those who disagreed were, implicitly, the enemies of the nation. The document pointed to the ongoing recession and the forecast of stagnation, and its apparent consequence, the fiscal crisis. The resolution to be taken for the fiscal crisis was eerily defined as 'very hard for the population as a whole' (ibid, p. 5). The fiscal crisis explained the high interest rates, which explained the low growth; thus 'the resolution of the fiscal crisis' would be necessary to resume economic growth. 'No ideological vision can change this' (ibid., p. 5).

The opposition was 'ideological'; the new administration would stick to 'reality'. The increase in savings would lead to low interest rates, which would lead to economic growth etc.. Years of theoretical reflections on the low probability of savings in itself fostering economic growth, such as by Keynes, Kalecki, Robinson and Kaldor, or the Economic Commission for Latin America (ECLAC), were ignored. In their place the Temer team adopted neoclassical macroeconomics. 'In the face of the fiscal crisis, the economy will remain stagnant or with very low rates of growth' (ibid., p. 7).

The document stated that tax increases should be avoided, generally speaking, not specifically. It ignored the fact that the rich pay low taxes in Brazil, postulating instead that 'any long-term adjustment should, in principle, avoid raising taxes, except in situations of extreme emergency and with broad social consent' (idem, p. 6). The text then begins a radical attack on the mandatory expenditures set out in the 1988 Constitution. This included retirement expenses, defined as another 'agent of the fiscal crisis'. As for this, the document did not attack tax evasion, or the unequal distribution of wealth, or the freedom to repatriate capital, or the exemption of taxes on distributed profits. It did not call for taxing those who should be taxed, given the supposed aim of achieving social equality through economic policies. Tax havens were not mentioned. The budget's main problems were 'on the one hand, the lack of space for increasing public revenues by raising the tax burden; on the other, the institutional rigidity that makes the public budget a permanent source of disequilibrium' (ibid., p. 5).

The document, therefore, affirmed that it was necessary to 'put an end to established constitutional ties, as in the case of health spending and education'. It was a daring step, a qualitative change of discourse, in which hypocritical verbiage about development gave rise to a sincerity that is typical of moments of exception. It would be no longer necessary to give priority to these compulsory expenditures. The payment of interest and dividends, $30 \%$ on average of Treasury spending, was not commented on. In fact, interest payments were being implicitly elevated to the government's own priority: fiscal security for the financial system; spending on education and health only if possible. The government euphemistically defined this proposal as a 'non-imposed budget', given the underlying radical hypothesis of the end of 'all ties'. The work also defined the need for the end of indexation, particularly of wages and pensions to the inflation rate, as established since the Lula administration. 'Each year, in the vote on the budget, the Congress will decide, together with the Executive, on the adjustments that will be made.' This would create a true paradise for capital, given the type of political representation that exists in Brazillian Congress today. In turn, it was officially stated that in return for this new regime, new legislation will seek to exterminate the remaining indexation contracts in the private world and the financial sector' (ibid., p. 10). Between 2016 and 2018, the government did not implement any measure related to this last topic.

Then the question of social security was mentioned. It should be reformed, with a general stretching of the contribution period, due, it was argued, to the aging population. 'It is necessary to introduce, even if progressively, a minimum age of less than 65 years for men and 60 years for women, with a future further escalation depending on the demographic data' (ibid., p. 12). Moreover, it would be necessary to eliminate 'the indexation of any benefit to the value of the minimum wage'. This led to a complete reversal of priorities: 'The minimum wage is not an income index, but a labor market instrument. The social security benefits depend on public finances and should not have real gains linked to GDP growth, [but] only protection of their purchasing power' (ibid., p. 12). If GDP varied by

${ }^{6}$ From here on, the translation is ours. 
$10 \%$ a year, it would be enough to 'keep the purchasing power of wages'. So, according to this, if the workers were judged to deserve a share of the growing additional output, this could be resolved through decentralized negotiations between capital and labour force, without 'interference' from the government and trade unions. In fact, these measures threatened a minimum income guarantees to the poor, the absolute majority of the population. This would be connected with a reform of labor legislation, discussed below.

The costs of 'swap' operations were also mentioned. Carried out by the Central Bank, they intend to keep stable the value of the Real against the Dollar. Such operations were to be 'avoided', because of their high apparent costs of state 'interference'. But what about the exchange rate itself? Should it be placed on a realistic level? No mention was made to this issue, nor any relevant strategy for a so-called 'national industry'; Temer would rely on an overvalued Real to control inflation rates, as Dilma. In the last part, the problem of 'development' was discussed. It repeated the now old mantra that the state should favor 'development' by creating a 'favorable business environment'. The document observed that 'we must prepare quickly for a trade liberalization that makes our productive sector more competitive, thanks to access to capital goods, technology and imported inputs' (p. 17). That is: forget about protecting and stimulating domestic manufacturing, the path historically followed by industrialized nations (see Chang, 2002, 2007). The path suggested by the document was liberalization in order to 'improve competition'. In Brazil, and other peripheral nations, such a policy had already been applied throughout the 1990's. The result was more denationalization and control of the domestic market by global oligopolies, and the prioritization of the export agenda (for Brazil, see Chang, 2007; see also Schincariol, 2006).

The document concluded with the need for limits for official expenditures, whose rates of change should be lower than the rate of change of GDP. It insisted on the need to carry out budget surpluses (primary) ${ }^{7}$, and 'to reach, in a maximum of 3 years, the stability of the Debt/GDP ratio' (idem, p. 18). A development policy focused on private initiatives should be implemented, through transfers of assets, broad concessions in all areas of logistics and infrastructure, partnerships to complement the provision of public services and the return to the previous regime of concessions in the petroleum area, changing Petrobras' preemptive rights. Regarding foreign trade, the objective was to:

[carry out] the full insertion of the Brazilian economy in international trade, with greater trade liberalization and the search for regional trade agreements in all relevant economic areas -the United States, the European Union and Asia- with or without the Mercosur, although preferentially with them (ibid., p. 18).

It should be noted that the Mercosur and the South America are, until today, the main destinations of Brazilian exports of manufacturing goods ${ }^{8}$. For Temer's supporters, in short, privileging the 'national' went after internationalization (denationalization).

Finally, the document affirmed that in the labor area 'collective agreements should be allowed to prevail over legal norms' (ibid., p. 19). There was no discussion of the rising unemployment rates or the industrial crisis. More broadly, the document did not mention Brazilian historical issues, such as racial inequality, excessive urban concentration, and the agrarian reform never sufficiently achieved. In short, the document was a collection of ideas already known and already applied, but which now appeared as an even more radical platform from the actions of a government that was not elected, in direct confrontation with the premises of the 1988 Constitution.

Between August 2016 and early 2018, the Temer administration would be able to pass a substantial part of such proposals in Congress. While the disjointed center-left forces observed more or less passively what happened, the Congress that had deposed Dilma rapidly approved most of the measures outlined in the document. It was a blitzkrieg strategy. In particular, the Congress approved

\footnotetext{
7 That is, revenues minus expenditures with the exclusion of interest payments.

${ }^{8}$ See http://www.mdic.gov.br/index.php/comercio-exterior/estatisticas-de-comercio-exterior/balanca-comercial-brasileiramensal-2
} 
the untying of health and education expenditures, removing the previously established minimums, and set a ceiling on government spending over the next twenty years. Such spending ceilings naturally excluded interest payments, and would be adjusted only for inflation in the next years. This was the proposal of Constitutional Amendment No. 95, made law on 15 December 2016, or the 'the end of the world' law, as it popularly became known'.

Labor reform would be approved, in the form of Law 13467. In particular, the new law envisaged: the regulation of 'teleworking' (teleworking using the world wide web); the prevalence of collective agreements on legislation; the permission for outsourcing of 'activities-end' (and not only 'activitiesmeans'); and allowance for pregnant women in unhealthy environments. One of the most striking changes was the approval of the mandatory end of unions' withholding contributions from wages, weakening their power. The regime of oil exploitation returned to the old conditions of 'concessions' of the (neoliberal) era of former president Fernando Henrique Cardoso (1994-2002), in which the state did not own the oil extracted (for a discussion of the differences, see Carta Capital, 09/21/2015). The government would hold auctions for the sale of pre-salt areas, generally bought by foreign companies, including Chinese (El País, 10/27/2017). Petrobras began adjusting prices on a daily basis -a wellregarded policy according to its shareholders- and sold many assets under the management of Pedro Parente. In the meantime, the government tried to sell sectors of the Embraer company to the US company Boeing, which would be finally realized in the commercial jets sectors (Folha de São Paulo, $07 / 17 / 2018)$.

However, the government did not reform the official Social Security system. The privatization of Eletrobrás was also not concluded. Successive allegations of corruption against members of the government, including the president himself, coupled with the unpopular measures now underway and also high unemployment, in sharp contrast to the promises made- led to the rapid fall of the popularity of the president. This weakened the proposal and the vote in the Congress itself, whose members now looked to the 2018 elections. The answer to the failure of the Social Security reform would be the announcement of a military intervention in the state of Rio de Janeiro, sponsored by the federal government shortly after the 2018 carnival.

Apparently the novelty of the intervention could erase the fiasco of the unfulfilled promises and the shadow of the accusations of coup. With the military intervention, the government also hoped to persuade large sections of the political right-wing electorate, perhaps giving some hope for Temer's still proposed re-election campaign. It also attracted the support of the Armed Forces. By degrading the role of the elected government of that state, Temer praised the (conservative) military, handing over the administration of the State of Rio de Janeiro to a general. With this, he rehabilitated the idea, until then discredited, that the corporation had something to say about the direction of the country's social and economic issues.

In April 2018, former President Lula was arrested after a second-instance trial (something which was contrary to the 1988 Constitution), after the decision of Paraná's Public Prosecutor's Office and the majority of the Federal Court of Justice. They attributed to Lula a flat given as a bribe, but the property was not registered in his name. The authorities were not acting legally, according to the revelations of Glenn Greenwald and The Intercept in 2019 (see also Sieder et alii 2005 for judicialization of politics). On May 1, a building collapsed in the center of São Paulo; it was occupied by social movements. There were several fatalities. Temer came, but had to leave in a hurry, booed and stoned. The daily price readjustments made by Petrobras led to increasing prices of diesel. It caused a national strike by truck drivers at the end of May, with great economic costs and a new shake-up of an already mediocre GDP. The Temer administration (unwillingly) met the demand for cheaper diesel but burdened the National Treasury and not Petrobras and its shareholders; and gasoline prices rose as a form of compensation for the company. The victory of the strikers led to Parente's resignation request (Valor Econômico, 06-01-2018). Analysts began to forecast a lower rate of economic growth. Finally,

\footnotetext{
${ }^{9}$ However, it was not possible to eliminate a series of compulsory expenditures, giving up (temporarily?) the setting of a 'zero budget'. But the proposal continued to be supported, as by Delfim Netto in Carta Capital (02/05/2018).
} 
the World Cup in Russia and the attention that the event traditionally attracts in Brazil brought to an end, practical purposes, the initiatives of the Temer administration, giving way to the electoral campaign period at the same time in July. Lula, in jail, was still leading the polls $(O$ Globo, 10/06/2018). As Temer did not exceed 8 percent of approval, according to most opinion polls, his campaign was abandoned.

Given this turn of events, we now proceed to an evaluation of the economic performance of the Brazilian economy, from August 2016 to May 2018. Did those pro-market economic measures have the effect of a significant reactivation of the macroeconomic environment, the labor market and the budget situation?

\section{The Brazilian economy between 2016 and the 2018 elections}

This section offers a general description and evaluation of the Brazilian economic performance from 2016 to 2018. In 2016 GDP shrank by $3.6 \%$. It was the biggest recession since the 1940 s. 'If we look at the biennium, the retraction was $7.2 \%$. We never had a biennium with a cumulative drop such as these', observed Rebeca de La Rocque Palis, coordinator of the National Accounts in charge of IBGE (O Globo, 15/03/2017). In 2017, GDP growth reached 1\%, a meager rate in the face of the huge gap between potential and real GDP left by the immediately preceding period. Over 2017, official unemployment, as measured by the National Survey Domicile Samples (PNADC), decreased slightly, but remained high (in the 12\% range), resuming an upward trend in 2018. The variations in the total number of employees in the economy showed a remarkable stability in face of the business cycles, with higher drops for the GDP rate between 2014 and 2016. The partial recovery of the GDP in 2016 was not followed entirely by the total employed workforce. This is partially explained by the high level of informal jobs in the economy (see IBGE 2019). Figure 2 suggests that the Brazilian economy entered a new 'labor saving' phase after 2017. The recovery of the GDP outweighed the employment rates since 2016. This suggests, in general terms, a new round of adoption of labor-saving techniques and/or utilization of existing capital with less use of the labor factor in the economy as a whole, particularly imported, depressing the employment rate (as with distance learning in education institutes; 'e-commerce'; automatized telephone services; robotization etc.) ${ }^{10}$.

In fact, the performance of the unemployment rate throughout the 2016-2018 interlude did not denote a qualitative improvement of the perilous situation inherited from the second Dilma administration. With regard to the private sector, which accounts for approximately 90 per cent of the country's total workforce ${ }^{11}$, the number of employees hired without a formal contract ('carteira assinada') rose from 27 per cent to almost 34 per cent of the total employment between 2015 and 2018 (May). This represented a reversal of the trend seen between 2012 and 2014, in which the formalization of wage labor in the private sector increased. The number of individuals working with a formal contract showed, in turn, a sharp downward reversal since mid-2014, when this modality reached a peak of 36 million individuals hired. This inversion continued its downward trend between 2016 and 2018. In general, as Figure 3 above shows, the hiring of workers with a formal contract continued to fall throughout the Temer administration, with a corresponding increase in the other modality (informal contracts).

The issuance of new employment cards ('carteira de trabalho', or formal work permits), according to the Ministry of Labor ${ }^{12}$, also showed a stagnant trend between 2016 and 2018. The average issuance

\footnotetext{
10 Imports of machinery and equipment, after a rapid rise between 2005 and 2011, fell sharply after 2013. This drop continued until the end of 2016. This drop was then interrupted. From there on, imports rose from 774 million dollars in April 2017 to 1,013 million in May 2018; see www.ipeadata.gov.br, 'Importações - setor: máquinas e equipamentos'. Accessed $07 / 23 / 2018$

11 See International Labor Organization (ILO), 'Share of employment in the public sector by sex', in http://www.ilo.org/ilostat Accessed 10/13/2016.

12 See http://trabalho.gov.br/dados-abertos/2016-02-27-16-59-42
} 
of permits in 2015 reached 444 thousand; in 2016, 383 thousand; and in 2017, 403 thousand. The average between January and May 2018 reached 453 thousand new issues, a difference of approximately only fifty thousand individuals with regard to 2017. In order to have an idea of what this represents in approximate terms (excluding work permits issued to the older working population [no available data]), in the year of 2000, 3.6 million individuals were born, according to IBGE13. A share of these individuals, approximately the $40 \%$ (1.4 million) that was not attending university or other types of higher education institutes ${ }^{14}$, could or should be entering directly into the labor market between 2016 and 2018. So, the approximate gap of the formal work contracts is then one million. Considering that a relevant part of the students also work, the gap in the formal labor market is still higher. In any case, in general terms, the issuance of new work permits between 2017 and 2018 did not cover a quarter of those individuals who were born at the beginning of the 21st century (19992000).



Figure 2. Brasil. GDP and total employment (14 years aged or more employed). Accumulated rate on a quarterly basis (\%). 2012-2018. Source: IBGE - Pesquisa Nacional por Amostra de Domicílios Contínua (PNDA Contínua) and Sistema de Contas Trimestrais.

The ratio between the income of the richest $10 \%$ and the lowest income $40 \%$ was 11.9 times in 2015 to 12.5 times in 2016 (IBGE, 2017b, p. 21). An ECLAC report on social conditions in Latin America also pointed to the worsening of poverty rates in the area (ECLAC, 2017a, p. 24). In sectoral terms, the quarterly national accounts published by the IBGE pointed to a fall of one percentage point in the participation of the manufacturing industry in the GDP between May 2016 and early 2018, measured in terms of current values. The manufacturing industry, which reached $15 \%$ in 2009 , had a share of only $9 \%$ of the GDP in January 2018. Real estate activities, one of the pillars of growth throughout the 2000s, stagnated at $8 \%$ of GDP during the period, and suffered the consequences of the alleged 'anti-corruption' operations carried out by the Federal Public Prosecutor's Office in Curitiba. Large construction conglomerates that still had national bases, as well as Petrobras, were affected. This operation added to the other economic effects to create a severe economic crisis.

As regards the economy as a whole, Table 1 shows how agribusiness, a sector immune to the crisis until then, saw a fall in its share of GDP, ranging from 5 to $4 \%$-particularly due to a lower rate of

13 In 2001, 3.5 million were born. See www.ipeadata.gov.br, 'População'. Accessed 07/23/2018.

${ }^{14}$ See http://www.brasil.gov.br/editoria/educacao-e-ciencia/2015/12/numero-de-estudantes-universitarios-cresce-25-em10-anos. Accessed 07/23/2018. 
growth in China. The rest of the 'real' economy was filled by the broad, dominant service sector $(70 \%$ of the workforce by 2016).

The financial sector, which amounted to 6\% of GDP in 2016, reached 6\% in 2017 and 8\% in 2018. This is particularly interesting in light of the sustained fall in interest rates led by the Central Bank in the period (see below); it helps to corroborate the more general observations of authors such as Piketty (2014) and also Robinson (1962), opposing the growth of finance and the growth of the real economy. Manufacturing and real state stagnated.

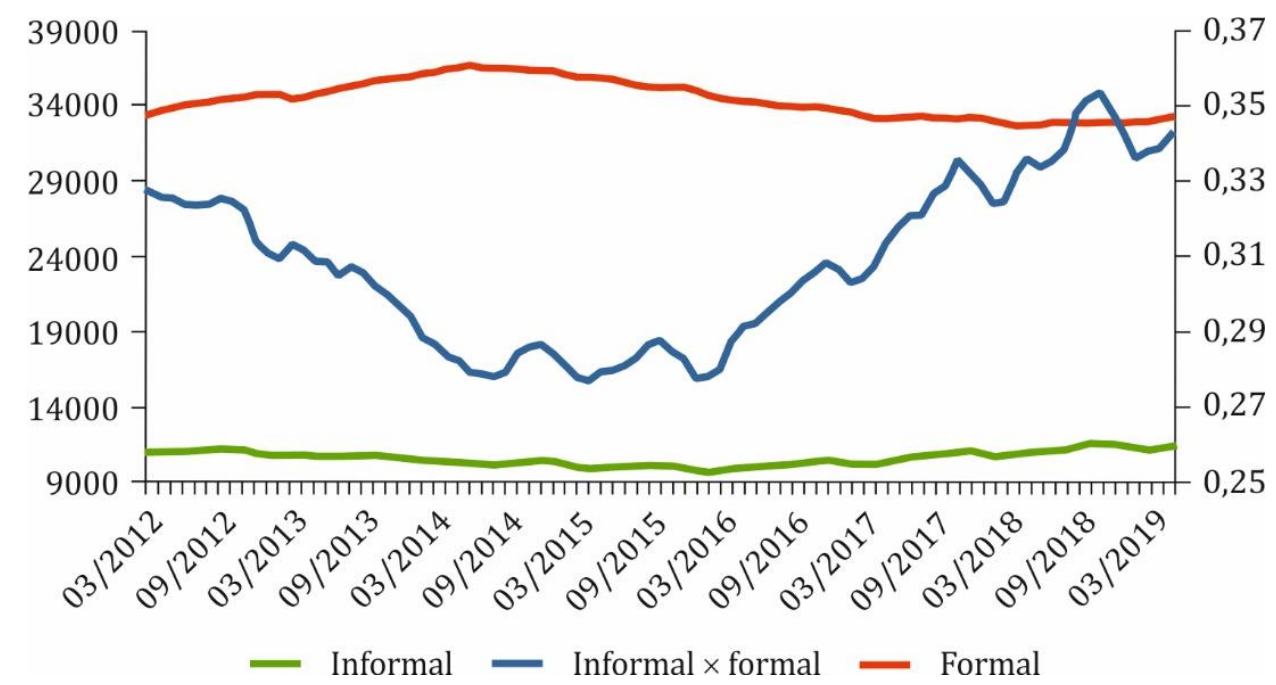

Figure 3. Brazil. Workforce: Formal and informal contracts (thousands -left axis) and relation between formal and informal contracts (right axis). 2012-2019 (March). Source: Brazilian Central Bank ('Empregados no setor privado com carteira' e 'Empregados no setor privado com carteira').

Table 1. Brazil. Main components of aggregate demand. 2015-2018 (\%). Current reais

\begin{tabular}{lccccccccc}
\hline & $(1)$ & $(2)$ & $(3)$ & $(4)$ & $(5)$ & $(6)$ & $(7)$ & $(8)$ & $(9)$ \\
\hline 2015.II & 0,10 & 0,06 & 0,08 & 0,05 & 0,20 & 0,18 & 0,63 & 0,13 & 0,14 \\
2015.III & 0,11 & 0,06 & 0,08 & 0,04 & 0,19 & 0,18 & 0,64 & 0,14 & 0,15 \\
2015.IV & 0,10 & 0,06 & 0,08 & 0,03 & 0,22 & 0,16 & 0,65 & 0,14 & 0,14 \\
2016.I & 0,10 & 0,07 & 0,09 & 0,06 & 0,19 & 0,17 & 0,65 & 0,13 & 0,13 \\
2016.II & 0,09 & 0,07 & 0,08 & 0,06 & 0,20 & 0,16 & 0,63 & 0,13 & 0,12 \\
2016.III & 0,10 & 0,07 & 0,08 & 0,05 & 0,19 & 0,16 & 0,64 & 0,12 & 0,12 \\
2016.IV & 0,10 & 0,07 & 0,08 & 0,03 & 0,23 & 0,15 & 0,64 & 0,11 & 0,11 \\
2017.I & 0,10 & 0,07 & 0,08 & 0,06 & 0,19 & 0,15 & 0,63 & 0,12 & 0,11 \\
2017.II & 0,10 & 0,07 & 0,08 & 0,05 & 0,20 & 0,15 & 0,63 & 0,13 & 0,11 \\
2017.III & 0,09 & 0,07 & 0,08 & 0,04 & 0,19 & 0,16 & 0,64 & 0,13 & 0,12 \\
2017.IV & 0,10 & 0,07 & 0,08 & 0,03 & 0,22 & 0,16 & 0,64 & 0,12 & 0,12 \\
2018.I & 0,09 & 0,09 & 0,09 & 0,06 & 0,19 & 0,15 & 0,64 & 0,13 & 0,13 \\
2018.II & 0,09 & 0,08 & 0,08 & 0,05 & 0,20 & 0,15 & 0,63 & 0,14 & 0,13 \\
2018.III & 0,10 & 0,08 & 0,08 & 0,04 & 0,19 & 0,17 & 0,64 & 0,17 & 0,17 \\
2018.IV & 0,10 & 0,08 & 0,08 & 0,03 & 0,21 & 0,16 & 0,65 & 0,16 & 0,15 \\
\hline
\end{tabular}

Notes: (1) Manufacturing industry; (2) Financial activities; (3) Real state; (4) Agribusiness; (5) Government Consumption; (6) Gross capital formation; (7) Consumption of the families; (8) Exports; (9) Imports. Source: IBGE Quarterly accounts. 
From the point of view of the structure of demand and supply, gross capital formation and government consumption relative to GDP stagnated over the period. Imports shrank in percentage terms till 2018.III, going from 13 to $11 \%$ of GDP, reflecting the recession and then the continued low domestic growth. This happened even during a period when the exchange rate did not show significant devaluation (see table 2). The partial recovery of the economy in 2017 led to higher levels of imports to the GDP. Exports grew in the same proportion in percentage terms, from 11 to $14 \%$ between 2016 and 2018, which translated into higher export/import ratios, interrupting the profile seen since 2004 . This showed more a shrinkage of the domestic market than a superior export dynamics, as trade balances were operating at the base of twenty billion dollars, below the peak reached in the 20102014 interlude.

Table 2. Brazil. Real and nominal exchange rate: Real/Dollar. Source: Brazilian Central Bank and Bureau of Economic Analysis

\begin{tabular}{lcccc}
\hline Year & $\begin{array}{c}\text { Nominal R\$-US\$ } \\
\text { Exchange rate } \\
\text { (average) }\end{array}$ & $\begin{array}{c}\text { Brazil } \\
\text { consumer } \\
\text { prices (IPCA) }\end{array}$ & $\begin{array}{c}\text { Consumer Price } \\
\text { Index (USA) }\end{array}$ & $\begin{array}{c}\text { Real Exchange } \\
\text { rate R\$-US\$* }\end{array}$ \\
\hline 2015 & 3,33 & 10,67 & 0,7 & 3,03 \\
2016 & 3,29 & 6,29 & 1,26 & 3,13 \\
2017 & 3,19 & 2,95 & 2,1 & 3,16 \\
2018 (March) & 3,26 & 0,7 & 0,6 & 3,25 \\
\hline
\end{tabular}

Note: $*$ Real exchange rate $=$ nominal exchange rate $\mathrm{x}$ inflation abroad (USA)/Domestic inflation.

Despite the reduction of exchange rate swap programs by the Central Bank, a real appreciation remained. The government ignored its relation with the weakening of domestic industrial manufacturing. The government fulfilled its promise to reduce swaps, but this did not mean allowing the real to depreciate significantly. This favored the conversion of the Brazilian Real into Dollars for local oligopolies, which is the underlying cause of an appreciated Real. The stable values of the US interest rates, coupled with trade surpluses and the maintenance of almost 400 US $\$$ billion dollars by the Central Bank, also helped to keep the Real at its usual value between 2016 and 2018. This simply meant not addressing the issue of the need for a currency devaluation, ignoring the literature criticizing the shrinkage of the manufacturing base in the country (even if controlled by multinationals; see Oreiro 2016). As with the exchange rate, there were no significant fluctuations in the other capital markets, particularly in Bovespa, indicating the implicit consent of the corporate world to the policies implemented by the Temer administration. An appreciated Real tended to benefit, precisely, the gains of multinationals in hard currency. Even the higher depreciation of the Real in 2018 -1 US\$ dollar reaching approximately 3,65 R\$ on average- was not enough to halt the crisis in Brazilian manufacturing sectors, with spending on tourism having increased significantly once again between 2016 and 2018 .

In fact, in two years of 'pro-market' administrations and widespread relief in the corporate sector over Dilma's overthrow, the Temer administration had been unable to alter the steady course of the Brazilian economy seen since 2011, with a brief interruption in 2013. Throughout the 2016-2018 interlude, gross fixed capital formation (GFCF) in the country fell to its lowest value since 1995: from $18 \%$ in 2015 , it would fall to only $16 \%$ in 2018 . With such a decline, the so-called need for external savings (domestic savings minus gross capital formation) has diminished. This meant the reduction of the indebtedness of local oligopolies to global financial houses, giving a lower rate of economic growth. Household consumption stagnated at 63-64\% of GDP. Neither low prices nor pro-market reforms have led to significant growth in the economy, contrary to the general prospects of the neoclassical literature which was a reference to the new policy makers.

15 See 'Viagens - pessoais - outros, inclusive turismo - mensal - despesa', Brazilian Central Bank. Accessed 07/23/2018. 
This meant, roughly speaking, that the $1 \%$ rate of economic growth of the economy in 2017 and the large under-utilized capacity left by the previous massive recession was the cause of Brazil's trade surpluses, and not a rebound in the domestic export-led sectors. The government consumption did not drop significantly, contrary to what was promised in the program to reduce the state's role of that administration. This, however, this was more due to the impossibility of reducing the compulsory expenditures of the Union, coupled with the low rates of change of GDP in 2016 and even 2017.

It is also worth mentioning that the utilization of general productive capacity in the economy reached the value of only $73.3 \%$ in the first quarter of 2018 , similar to the one in the second quarter of 2016. This value for the first quarter of 2018 is lower, in terms of the historical series, than the values referring to the macroeconomic impact of the two 'Collor Plans' (1990-1991). The value is even lower than the values reached during the peak of the 2008-2009 crisis, when capacity utilization in Brazil reached $76.2 \%$. From this point of view, too, the Temer administration had failed to resume economic growth in Brazil. The reforms did not have short-term effects, particularly in relation to the overcoming of the 'uncertainty'.

As mentioned above, the Dilma administration had suffered an impeachment in the National Congress which was based on arguments linked to alleged mismanagements, or irresponsibility. In fact, the opposition's allegations were not accurate. The net debt of the National Treasury in terms of the Gross Domestic Product fell from January 2006, still in the first Lula administration, until mid2014. There was a strong upward oscillation in the context of the impacts of the 2008-2009 crisis on the Brazilian economy. But this oscillation was then corrected in the first Dilma administration, in which indebtedness in terms of GDP declined steadily, reaching only 17\% in February 2014 . This was simple: the country still had some economic growth.

The macroeconomic environment changed after 2012-2013. In fact, the sustained fall in GDP growth rates since 2011 has led to lower tax revenues. This was responded to with a conscious (i.e, counter-cyclical) increase in current expenditures by the then Minister of Finance Guido Mantega (2011-2014), with Dilma's approval. This has led to a relative increase in Treasury indebtedness. But far from a supposed intrinsic 'irresponsibility' of the PT administrations, it was a choice of economic policy -which, even, was intended to please the corporate sector, with fiscal incentives. In August 2016, indebtedness in terms of GDP reached 26\%. The Treasury's indebtedness in the period was then linked, first and foremost, to the fall of the domestic growth and the several fiscal incentives, together with other official expenditures. This 'Keynesian/Kaleckian' policies -or conditions, given that most of the Latin American nations also saw growing budget deficits in this period (see ECLA 2017b)- were based partially on a certain interpretation of reality. Despite the barrage of aggressions that Dilma received urbi et orbi, such a policy could not simply be seen as 'populist'. The real problem was that Dilma did not dare to leave the Real depreciate enough to counter the trade deficits, which grew from 9\% to 14\% of the GDP between 2011 and 2014 (see also Schincariol, 2017).

The supporters and ministers of Temer's administration pronounced themselves particularly virulently on this increase in central government indebtedness under Dilma, in parallel with increases in primary and nominal deficits by May 2016. But once in power, they failed to improve the fiscal position of the Brazilian National Treasury in terms of debt-to-GDP ratio (one of the promises of 'Bridge to the Future'). On the contrary, indebtedness in GDP terms grew rapidly. With regard to the April 2016-December 2018 period, the Central Government (National Treasury, Central Bank and Social Security) operated in nominal deficit in all but two months (October 2016 and January 2018). The primary results required for interest payments did not perform much better, with only nine months of positive values between April 2016 and December 2018. Those in favor of the government blamed the mandatory constitutional expenses. However, where would the GDP growth rates be if government spending had fallen even more since 2016 ?

In fact, there was a tendency for the stabilization of the primary deficit, and even of the nominal deficit of the Treasury. This was reduced from 7.6\% of GDP in 2016 to $7 \%$ of GDP in 2017; the primary deficit fell from $2.5 \%$ to $1.8 \%$ of GDP in the same period. This denoted that the government made cuts in discretionary spending as it could, and renounced the counter-cyclical role of the budget over the 
two years. These reductions -in Kaleckian terms at least -partially explained the situation of a low GDP growth and jobs. However, in the light of stagnant tax revenues, these primary deficits remained and had to be financed, something which the government managed to do even in the light of the systematic dropping of the SELIC (Sistema Especial de Liquidação e Custódia - the official interest rate). Interest payments fell in relative and absolute terms. This was due to the systematic lowering of the SELIC level, set by the Central Bank for public bonds and reference to others (also affecting the issued short and medium term debt bonds). The SELIC was lowered by the Central Bank since May 2016, from $0.05 \%$ per day to $0.02 \%$ per day in mid-2018. In fact, maintaining a higher bias for the SELIC interest rate would make the economic scenario so critical that this would prevent any governability. Even so, at the turn of 2016 to 2017, there was a sharp jump in National Treasury indebtedness in terms of GDP, which reached 32.8\%. The value continued to rise until reaching 38\% in February 2018 and $40 \%$ in December 2018. To the financial capital, the Temer team offered the privatization of Social Security, and its aforementioned 'pro-market' reform package, as compensations.

The other compulsory expenditures were stabilized. Social Security spending oscillated around R\$ 44 billion a month, with only a slight upward trend. It should be noted that in February 2018 they accounted for $41 \%$ of government expenditures, but they were distributed over a much larger population than the public debt holders, many of whom were foreigners $(13 \%$ according to the Central Bank). Personnel expenses and social charges continued to expand next to GDP growth rates. Finally, there was a significant reduction in some decisive government discretionary spending, particularly those linked to the Growth Acceleration Program (PAC, 'Programa de Aceleração do Crescimento'), which was linked to infrastructure development programs. It helps to explain the reduction in the capital formation above mentioned ${ }^{16}$. In sum, the government reduced interest rates, reduced nominal deficits in terms of GDP, but failed to reduce indebtedness, and failed to behave as an element of additional aggregate demand in this period, when the economy was (i) in recession and then (ii) semistagnant, with deterioration of social conditions and even impoverishment of large fractions of the socalled middle classes.

Regarding the balance of payments, in addition to the cyclical, political and other factors explaining the enormous inflection of the economy since 2012, the stagnant performance of the country was in structural terms highly related to the continuity of an inflection of the foreign trade, which begun in August 2011. Graph 5 below shows a high correlation between the performance of the country's trade balances and GDP changes since 2000. This correlation was not only the direct multiplier effect of exports, but also of the improvement in the fiscal situation of the government, which was able to create more conditions to invest and spend more. It should be noted that trade balances were high from the 2000s onwards, helping to pull the increasing GDP variances up to 2007. But as the period 2016-2018 has elapsed, GDP and foreign trade were maintained, which denoted the importance of the internal factors for the interruption of growth (decrease in 'PAC' spending, large groups affected by the 'Lava a Jato' operation, mass layoffs, 'uncertainty' etc.).

The increasing trend in the trade balance since 2006 was accompanied by a greater fluctuation of the GDP between 2007 and 2011, with both variables declining thereafter. The impeachment process occurred in one of the most depressed moments for the export sectors, with an average of 13 billion a month in April 2016. Exports continued to decline until practically March 2017, but as imports fell even more steadily, net balances increased. At the beginning of 2016 a recovery of the volume sold abroad was started, in parallel with stagnant imports, resulting in a lower total trade (I + E). Trade balances then take off from GDP. The level of imports declined, and exports resumed a certain upward trend, albeit at a lower level than historically reached. This is the reason for the trade surplus, to translate a semi-stagnant economy, which led to the reestablishment of structural unemployment in 2002-2003.

16 This information was available in 'Resultados Primários do Governo Central', Table 1.1, Line 69, on http://www.tesouro.fazenda.gov.br/-/resultado-do-tesouro-nacional. The table was accessed on 07-22-2018, but its new version does not show results for PAC anymore. 


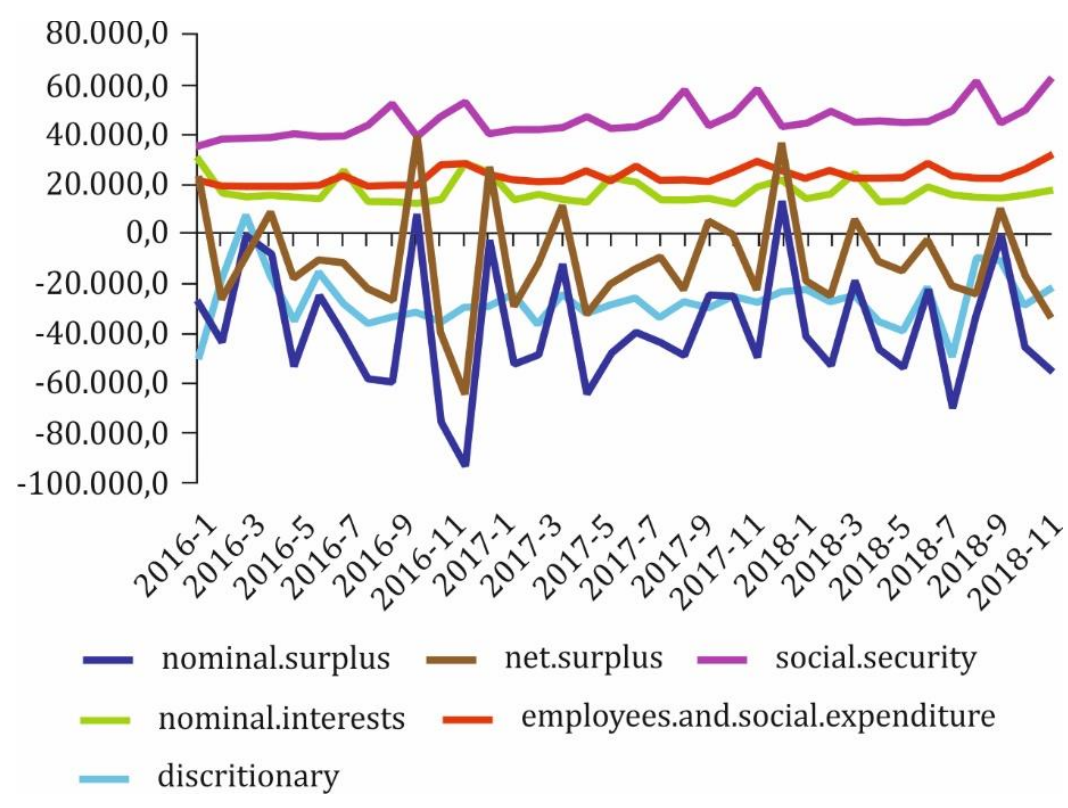

Figure 4. Brazil. Central government expenditures (R\$ million - current). 20162018. Source: Central Government (Secretaria do Tesouro Nacional).

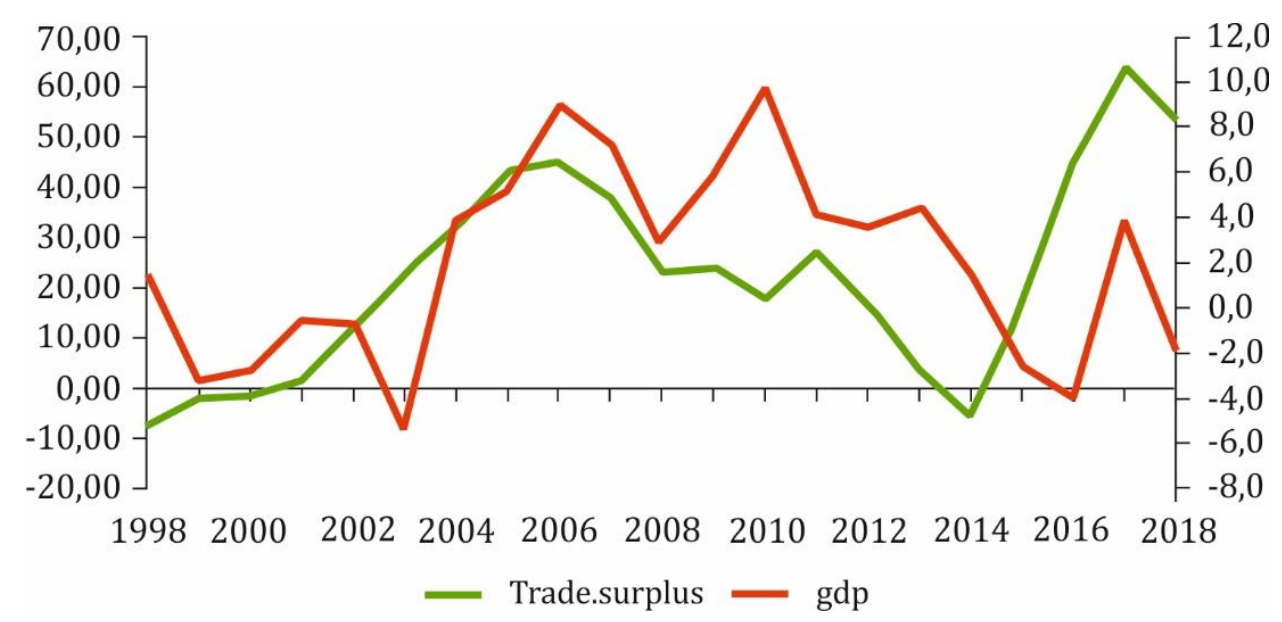

Figure 5. Brazil. International trade in goods and services (US\$ billions -left axis) and GDP growth rates (\% -right axis). 1998-2016. Source: Brazilian Central Bank.

The level of foreign direct investment (FDI) in the economy since 2016 has remained high, much of which for the purchasing of existing assets (see Table 3 below). Inflows always outperformed the remitted net profits. Apparently, Brazil continued to gain from external savings. However, it implied loss of control of the domestic investment decisions. According to the Central Bank, the average rate of foreign direct investment in the country since 2003 was 1.20 times. The GDP growth rate in dollars, measured by the Central Bank, was 1.004 times. This gave the approximate measure in which the Brazilian economy became denationalized, losing more and more control over investment decisions, which are being increasingly from outside the country. They are beyond the reach of the direct or even personal influence of the public administrations. The level of FDI growth and economic growth has been the same between 2016 and 2018, at around 4\% of GDP. As we saw, this was not a problem for 
the Temer administration, since there would be no qualitative consequences for the country arising from different types of control of the investment decisions. This interpretation implicitly assumes that Brazil is an important international player.

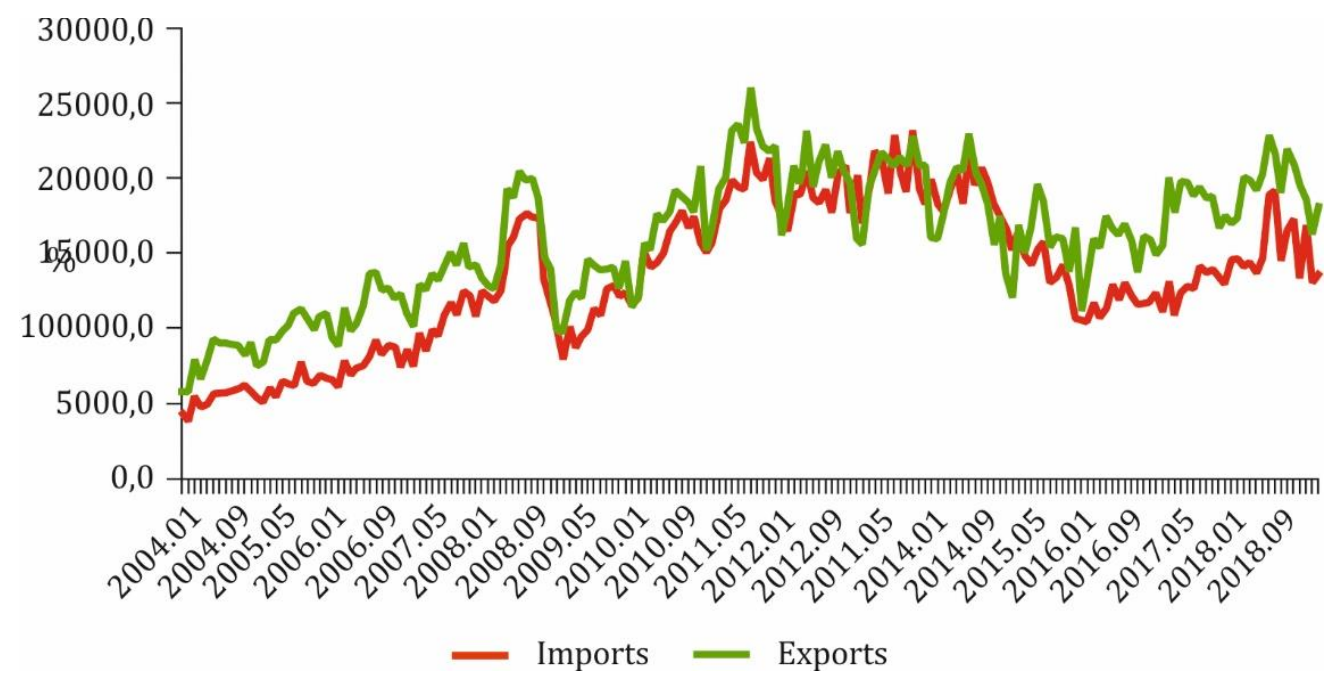

Figure 6. Brazil. Trade in goods and services. 2004-2018. US\$ million. Source: Brazilian Central Bank.

Table 3. Brazil. Balance of payments. May 2016 - march 2018. US\$ million

\begin{tabular}{lcccc}
\hline & $(1)$ & $(2)$ & $(3)$ & $(4)$ \\
\hline May/16 & $-826,3$ & $6.148,40$ & $-731,4$ & $-1.965,00$ \\
Jun/16 & $-688,8$ & $3.920,20$ & $-565,1$ & $-125,3$ \\
Jul/16 & $-856,6$ & 209,00 & $-531,9$ & $-5.264,90$ \\
Aug/16 & $-628,8$ & $7.207,70$ & $-679,8$ & $1.070,90$ \\
Sep/16 & $-222,9$ & $5.273,60$ & $-626,5$ & $-328,2$ \\
Oct/16 & $-834,9$ & $8.399,60$ & $-659,1$ & $-3.834,00$ \\
Nov/16 & $-1.235,30$ & $7.970,00$ & $-339,7$ & $-3.368,40$ \\
Dec/16 & $-3.163,90$ & $15.285,70$ & -382 & $-2.620,30$ \\
Jan/17 & $-281,4$ & $11.458,50$ & $-344,6$ & $-3.096,60$ \\
Feb/17 & $-1.512,90$ & $5.263,10$ & $-347,4$ & $-2.027,30$ \\
Mar/17 & $-745,6$ & $7.059,60$ & $-275,7$ & 501,8 \\
Apr/17 & $-166,5$ & $5.566,10$ & $-254,1$ & $-1.558,60$ \\
May/17 & -973 & $2.892,40$ & -231 & $-58,8$ \\
Jun/17 & $-910,2$ & $3.981,60$ & $-203,5$ & $4.350,60$ \\
Jul/17 & $-1.522,10$ & $4.059,30$ & $-187,2$ & $-3.089,80$ \\
Agug/17 & $-1.549,20$ & $5.151,60$ & $-172,8$ & $-1.772,20$ \\
Sep/17 & $-733,5$ & $6.341,80$ & $-429,4$ & $1.629,00$ \\
Oct/17 & $-892,6$ & $8.129,70$ & -409 & $-621,9$ \\
Nov/17 & $-1.153,90$ & $5.021,30$ & $-383,5$ & $-891,00$ \\
Dec/17 & $-2.918,40$ & $5.407,40$ & $-387,8$ & $1.477,10$ \\
Jan/18 & 825,4 & $6.465,70$ & $-388,5$ & 691,8 \\
Feb/18 & $-333,3$ & $4.742,50$ & $-393,1$ & $-5.724,40$ \\
Mar/16 & 214,4 & $6.539,00$ & $-398,1$ & $5.967,80$ \\
\hline
\end{tabular}

Notes: (1) Distributed income of corporations - Net - US\$ (million). (2) Direct investment - net - US\$ (million). (3) Reinvested earnings - US\$ (million). (4) Portfolio investment - Fixed income Liabilites - US\$ (million).. Source: Central Bank. 
In any case, given the average investment rate of 15 percent in terms of GDP over Temer's administration, of every three Reais of investment decisions in Brazil, one Real (33 percent) was foreign. This amount is slightly higher if the capital contributions in shares, measured in the financial account of the balance of payments, are considered. Portfolio investments, after vertiginous growth up to 2015 (when public indebtedness in terms of GDP declined), were inflected from 2015 onwards, operating at a much lower level. This partially reflected the fall in the SELIC rate since 2016, although 'sovereign risk levels have been reduced in almost all the countries of the region since the beginning of 2016, in accordance with the lower tensions observed in the world financial markets' (ECLA, 2017b, p. 44). This reduction included Brazil, which had a risk index of sovereign bonds, according to J.P. Morgan, that fell from 548 to 237 between 2015 and 2017 (ECLA, 2017b, p. 44). Interestingly, as we have seen, this was a period in which central government indebtedness rose rapidly, which shows the bias of the international evaluations in favor of the administration that succeeded that of Dilma Rousseff, which were not correct in terms of the government indebtedness.

\section{Conclusions}

The global markets, as we could see, continued to invest in Brazil after the impeachment process, while at the same time traditional trade flows remained, albeit on a lower level. For the Temer government, this was a natural and necessary process. He had the implicit support of global and domestic markets. Even the main branches of the domestic bourgeoisie that were harmed by Temer's subservient policies -such as Odebrecht, Camargo Gutierrez etc.- would not support any 'antiimperialist front', something which would seem ridiculous to them all. On the other hand, the high levels of FDI were not enough to prevent the fall in the rate of gross capital formation and the subsequent rise of the unemployment rates. As the ECLA shows, Brazil was the nation that received the most FDI flows in Latin America, but it was one of the countries that had the lower economic growth rates in the period (2016-18) (see ECLA, 2017b, p. 31 and p. 48).

The larger part of the capital inflows bought existing assets, public debt, or went directly to financial channels, with little 'real' investment between 2016 and 2018. The government's budget position improved in terms of falling nominal and primary deficits, but there was a significant increase in the debt ratio of the National Treasury in terms of GDP. The drop in the SELIC rate reduced the amount of interest payments, but gross capital formation expenses were cut, particularly through an attack on 'PAC' expenditures, with the government seeking to compensate for such financial losses by attempting to downgrade the role of the Social Security -thus, trying to open a new and broad field of accumulation to the private banks. In general terms, the budget conditions to which the successive governments of the country became accustomed after 2004 was that of increasing exports and growing local markets; these conditions no longer characterized the scenario after 2014 and also the 2016-2018 period.

Brazil has been operating under conditions of exposure to global lending markets and their imports, with structural impediments to a deepening of its domestic markets. A growing part of the domestic investment decisions have been given out. It is doubtful whether this strategy allows the construction of a truly national path to face the future challenges of a typical peripheral state. As official data show, Temer's policies were not able to adequately remediate the increasing adoption of labor saving techniques by the oligopolies, after 2015 onwards. In fact, his polices aggravated unemployment: with the labor reform, it became easier to fire workers; with lower budget deficits, aggregate demand also contracted, and hiring was then negatively affected; and with a still overvalued real, imports of machines were encouraged. This path also indirectly reinforces foreign interference in the economy and even in the political life of the country.

From the point of view of the majority of the working people, therefore, the arguments of the government for the type of economic policies implemented were weak. With more unemployment and fewer social benefits, unequal distribution increased. In addition to increased unemployment and 
natural worsening of their living conditions, poor wage earners lost labor rights and suffered cuts in social benefits. The government increasingly retreated to minimum control over the rate of capital formation, either by denationalization, by the explicit option of dependence on external markets, by its own divestment and the call for more privatizations, and even by attending Petrobras' shareholders desires for short term gains. On the other hand, the government avoided changes in tax rules that could lead to income redistribution, and a realistic exchange rate policy connected to firm control over inflation through extended price controls and wage ceilings (for the higher ones). In fact, these measures would make any orthodox and even many 'heterodox' economists laugh in Brazil. It was very unlikely that even a center-left victory in 2018 would have substantially altered this outlook, as no party or social movement was building a successful resistance strategy.

Structural unemployment; threats to pensions; slow privatization of the national health and education system; attacks on trade unions; subcontracting of the workforce; elimination of jobs due to technological progress; denationalization; obscurantism, authoritarianism and religious influence in Congress: these were the general conditions that emerged, or were consolidated, during Temer's administration. With the maintenance and advance of this pattern of economic policies after the 2018 election of Bolsonaro, the more openly fascistic candidate, the Brazilian economy is likely to tend to a medium-long-term stagnation with sharpening structural heterogeneities and deteriorating racial and gender inequalities.

\section{References}

Anderson, P. (2006). Crisis in Brazil. London Review of Books, 38(8), 15-22.

Bacha, E., \& De Bolle, M. B. (Eds.). (2013). O futuro da indústria no Brasil. Rio de Janeiro, RJ: Civilização Brasileira. Banco Central do Brasil - Sistema Gerenciador de Séries Históricas. Retrieved from https://www3.bcb.gov.br

Barbosa, W. N. (2004). Políticas econômicas do governo e estagnação: duas décadas perdidas. 1980-2004. (Thesis of free teaching). São Paulo, SP: Universidade de São Paulo.

Bastos, P. (2012). A economia política do novo-desenvolvimentismo e do social-desenvolvimentismo. Economia e Sociedade, 21(no. spe.). DOI: https://doi.org/10.1590/s0104-06182012000400004

Berriel, T., Bonomo, M., \& Carvalho, C. V. de. (2013). Diversificação da economia e desindustrialização. In E. Bacha \& M. Baumgarten (Eds.). O futuro da indústria no Brasil. Desindustrialização em debate. Rio de Janeiro, RJ: Civilização Brasileira.

Bielschowsky, R. (2006). Pensamento econômico brasileiro. O ciclo ideológico do desenvolvimentismo. Rio de Janeiro, RJ: Contraponto.

Bonelli, R., \& Pessôa, S. A. (2010). Desindustrialização no Brasil: um resumo da evidência. Fundação Getúlio Vargas/Instituto Brasileiro de Economia. Texto para discussão, 7. Retrieved from http://bibliotecadigital.fgv.br/dspace/bitstream/handle/10438/11689/Desindustrializa\%c3\%a7\%c3\%a3o $\% 20$ no $\% 20$ Brasil.pdf?sequence $=1$ \&isAllowed $=\mathrm{y}$

Bresser-Pereira, L. C. (2007). Macroeconomia da estagnação. São Paulo, SP: Editora 34.

Bresser-Pereira, L. C. (2015). A construção política do Brasil. São Paulo, SP: Editora 34.

Carneiro, R. (2005). Desenvolvimento em crise. São Paulo, SP: Edunesp.

Chang, H.-J. (2002). Kicking away the Ladder. Development strategy in historical perspective. London, England: Anthem Press. DOI: https://doi.org/10.1108/10748120510618222

Chang, H.-J. (2007): Bad samaritans: The myth of free trade and the secret history of capitalism. London, England: Bloomsbury.

Comisión Económica para América Latina y el Caribe (2017a). Anuario estadístico de América Latina y el Caribe. Santiago de Chile, Chile: CEPAL. Retrieved from https://www.cepal.org/es/publicaciones/ae

Comisión Económica para América Latina y el Caribe (2017b). Balance preliminar de las economías de América Latina y el Caribe, 2017. Santiago de Chile, Chile: CEPAL. Retrieved from https://repositorio.cepal.org/bitstream/handle/11362/42651/117/S1701283 es.pdf

Cosenza, A. C. (2018). Calibã se liberta: o setor externo da economia brasileira (1999-2013). (Doctoral thesis). São Paulo, SP: Universidade de São Paulo. 2018. DOI: https://doi.org/10.11606/t.8.2018.tde-11072018-122743

Duarte, P. G., Silber, S. D., \& Guilhoto, J. J. M. (Orgs.). (2011). O Brasil do século XXI. São Paulo, SP: Editora Saraiva.

Economic Commission for the Latin America and the Caribbean. www.eclac.org 
Folha de São Paulo. https://www.folha.uol.com.br/

Estado de São Paulo, O. https://www.estadao.com.br/

Giambiagi, F., \& Além, A. C. (2008). Finanças públicas. Teoria e prática no Brasil. Rio de Janeiro, RJ: Editora Campus.

Globo, 0 . https://oglobo.globo.com/

Instituto Brasileiro de Geografia e Estatística [IGBE]. (2017a). Sistema de Contas Nacionais: Brasil: 2015. Rio de Janeiro, RJ: IBGE. Retrieved from https://biblioteca.ibge.gov.br/index.php/biblioteca-catalogo?view=detalhes\&id=2101289

Instituto Brasileiro de Geografia e Estatística [IGBE]. (2017b). Síntese de indicadores sociais. Uma análise das condições de vida da população brasileira 2017. Rio de Janeiro, RJ: IBGE. Retrieved from

https://biblioteca.ibge.gov.br/visualizacao/livros/liv101459.pdf

International Labor Organization. $<$ http://www.ilo.org/ilostat $>$

Ministério do Trabalho. < http://trabalho.gov.br>

Oliveira, F. DE. (2003). Crítica à razão dualista/O ornitorrinco. São Paulo, SP: Boitempo.

Oreiro, J. L. (2014). Macroeconomia do desenvolvimento. Uma perspectiva keynesiana. Rio de Janeiro, RJ: LTCLivros Técnicos e Científicos Editora.

Oreiro, J. L., \& Feijo, C. A. (2010). Desindustrialização: conceituação, causas, efeitos e o caso brasileiro. Revista de Economia Política, 30(2), 219-232. DOI: https://doi.org/10.1590/s0101-31572010000200003

País, El. https://elpais.com/

Piketty, T. (2014). Capital in the twenty first century. Cambridge, MA: Harvard University Press.

Pochmann, M. (2012). Nova classe média? São Paulo: Boitempo.

Prashad, V. (2007). The darker nations. New York, NY: The New Press.

Revista Fórum. https://revistaforum.com.br/

Robinson, J. (1962). Essays in the theory of economic growth. London, England: Macmillan.

Rodriguez, O. (2006). El estructuralismo latinoamericano. Romero de Terreros, México: Siglo XXI/CEPAL. Retrieved from https://repositorio.cepal.org/bitstream/handle/11362/1952/S3389R696E es.pdf?sequence=1\&isAllowed= y

Saad Filho, A., \& Arestis, P. (Orgs.). Political economy of Brazil: Recent economic performance. London, England: Palgrave.

Schincariol, V. E. (2007): O Brasil sob a crise do fordismo. São Paulo, SP: LCTE Editora.

Schincariol, V. E. (2012). Crescimento econômico no Brasil, 2003-2010: uma análise da política econômica e do padrão acumulativo. São Paulo, SP: LCTE Editora.

Schincariol, V. E. (2017). Economia e política econômica no governo Dilma, 2011-2014. São Paulo, SP: Raízes da América.

Schincariol, V. E., Barbosa, M. S., \& Yeros, P. (2017). Labor trends in Latin America in the current crisis (20082016). Agraria South, Journal of Political Economy, 6(1), 113-141. DOI: https://doi.org/10.1177/2277976017721319

Secco, L. (2011). História do PT. São Paulo, SP: Ateliê.

Secretaria do Tesouro Nacional. www.tesouro.fazenda.gov.br

Sicsú, J., De Paula, L. F., \& Michel, R. (Eds.). (2012). Desenvolvimentismo, um projeto nacional de desenvolvimento com equidade social. Barueri, SP: Editora Manole. 2012.

Sieder, R., Schjolden, L., \& Angell, A. (2005). The judicialization of politics in Latin America. London, England: Palgrave. DOI: https://doi.org/10.1007/978-1-137-10887-6 1

Singer, A. (2012). Os sentidos do lulismo. Reforma gradual e pacto conservador. São Paulo, SP: Companhia das Letras. DOI: https://doi.org/10.33026/peg.v14i1.2103

Sputnik News. https://sputniknews.com/

UOL Notícias. https://noticias.uol.com.br/

Valor Econômico. http://www.valor.com.br/ 